\title{
ABORSI BAGI KORBAN PEMERKOSAAN DALAM PERSPEKTIF ETIKA PROFESI KEDOKTERAN, HUKUM ISLAM DAN PERATURAN PERUNDANG-UNDANGAN
}

\author{
Ratna Winahyu Lestari Dewi \\ Suhandi \\ Fakultas Hukum Universitas Wijaya Kusuma Surabaya \\ e-mail:suhandi_fh@gmail.com
}

\begin{abstract}
ABSTRAK
Aborsi adalah masalah klasik dalam dunia kesehatan yang selalu menimbulkan perdebatan sepanjang zaman. Dari segi istilah aborsi berarti pengakhiran kehamilan sebelum janin itu dapat tumbuh diluar tubuh ibunya. Aborsi dibedakan menjadi dua yaitu aborsi spontan dan aborsi buatan. Aborsi buatan dibagi lagi berdasarkan alasannya, yaitu aborsi kriminalis dan aborsi medisinalis. Selama ini aborsi pada kasus korban pemerkosaan dianggap sebagai tindak kejahatan. Namun dengan berlakunya UU No. 36 Thn. 2009 tentang Kesehatan, aborsi bagi korban pemerkosaan telah dilegalisasi. Kembali masalah ini menjadi kontroversi dan menimbulkan pro dan kontra pendapat dalam menyikapinya. Tulisan ini akan membahas tentang aborsi dalam berbagai perspektif yaitu etika profesi kedokteran, hukum Islam dan peraturan perundangundangan di Indonesia. Dan aborsi bagi korban pemerkosaan memang bagai sembilu bermata dua. Tenaga kesehatan yang dihadapkan pada situasi tersebut akan mengalami dilema. Melakukan aborsi akan dihukum, tidak melakukan aborsi maka jiwa sang ibu hamil yang jadi taruhannya. Dengan memperhatikan bahwa pemerkosaan dapat menyebabkan trauma psikologis bagi korban, maka aborsi dilegalkan dengan memperhatikan pasal 75 ayat (2) huruf b UU No. 36 Tahun 2009 dan harus dilakukan oleh dokter professional sesuai dengan standar profesi serta memperhatikan ketentuan norma-norma dalam agama. Dalam tulisan ini akan dibahas tentang aborsi dalam perspektif etika profesi kedokteran, hukum Islam dan peraturan perundang-undangan dalam hukum positif Indonesia.
\end{abstract}

Kata kunci: aborsi, pemerkosaan, perspektif, etika,hukum Islam,

\section{ABSTRACT}

Abortion is a classic problem in the world of health that has always caused debate throughout the ages. In terms of the term abortion means the termination of pregnancy before the fetus can grow outside the mother's body. Abortion can be divided into two, namely spontaneous abortion and artificial abortion. Artificial abortion subdivided based on reason, namely abortion and abortion medisinalis criminalist. During this abortion in cases of rape victims are considered as a crime. But with the enactment of Law no. 36 years old. 2009 on health, abortion has been legalized for rape victims. Back problems are a matter of controversy, and raises the pros and cons of opinion in react. This paper will discuss about abortion in a variety of perspectives of professional ethics of medicine, Islamic laws and regulations in Indonesia. And abortion for rape victims is like a double-edged knife. Health workers who are faced with these situations will have a dilemma. Abortion will be punished, not doing abortion is the soul of the pregnant woman is at stake. Noting that rape can cause psychological trauma for the victim, then legalized abortion with respect to Article 75 paragraph (2) letter b Law No.36 of 2009 and should be done by a professional doctor in accordance with professional standards and observe the provisions of norms in religion. In this paper will discuss about abortion in the perspective of professional ethics of medicine, Islamic law and legislation in the positive law of Indonesia.

Keywords: abortion, rape, perspective, ethics, Islamic law,

\section{PENDAHULUAN}

Kesehatan adalah hal yang sangat penting yang dibutuhkan oleh setiap manusia dan merupakan salah satu kebutuhan pokok selain sandang, pangan dan papan. Dapat dipastikan bahwa tidak ada seorangpun yang ingin mengalami sakit dalam periode kehidupannya. Segala upaya akan dilakukan untuk sembuh dan meningkatkan kondisi 
kesehatannya. Sehubungan dengan hal tersebut, Bahder Johan Nasution berpendapat, bahwa:

Upaya peningkatan kualitas hidup manusia di bidang kesehatan, merupakan suatu usaha yang sangat luas dan menyeluruh, usaha tersebut meliputi peningkatan kesehatan masyarakat baik fisik maupun non fisik. Di dalam Sistem Kesehatan Nasional disebutkan, bahwa kesehatan menyangkut semua segi kehidupan yang ruang lingkup dan jangkauannya sangat luas dan kompleks. Dari pengertian di atas, dapat dipahami bahwa pada dasarnya masalah kesehatan menyangkut semua segi kehidupan manusia, baik kehidupan masa lalu, masa sekarang maupun masa yang akan datang. Dilihat dari sejarah perkembangannya, telah terjadi perubahan orientasi nilai dan pemikiran mengenai upaya memecahkan masalah kesehatan. Proses perubahan orientasi dan pemikiran dimaksud selalu berkembang sejalan dengan perkembangan teknologi dan sosial budaya. (Bahder Johan Nasution, 2005: 1)

Salah satu masalah dalam bidang kesehatan yang menimbulkan pro dan kontra adalah tentang aborsi. Aborsi merupakan masalah klasik yang menjadi bahan perdebatan sepanjang zaman. Seiring dengan berbagai perkembangan dan perubahan di era globalisasi ini, aborsi masih menjadi bahan kajian menarik untuk dibahas.

Saat ini kontroversi terkait aborsi kembali ramai dibicarakan dengan diundangkannya UndangUndang Nomor 36 Tahun 2009 tentang Kesehatan yang menggantikan Undang-Undang Nomor 23 Tahun 1992. Masyarakat beranggapan bahwa Undang-Undang yang baru ini telah melegalkan aborsi bagi korban pemerkosaan. Sebenarnya masalah aborsi sudah diatur dalam pasal 15 Undang-Undang Nomor 23 tahun 1992 tentang Kesehatan (selanjutnya disingkat UU No. 23 Tahun 1992). Dalam UU ini memang tidak diketemukan kata aborsi karena istilah yang digunakan adalah tindakan medis tertentu. Pengaturan melalui sistem hukum inilah yang dimaksud dengan legalisasi. Namun masyarakat merancukan makna legalisasi ini sama dengan liberalisasi. Padahal liberalisasi yang artinya pembebasan jelas berbeda makna dengan legalisasi yang bertujuan untuk mengatur.

Terdapat 3 ( tiga ) pendirian tentang aborsi, yaitu: (a) Pendirian konservatif: aborsi tidak boleh dilakukan dalam keadaan apapun juga. Di sini terdapat alasan-alasan keagamaan dan filisofis antara lain kesucian kehidupan, larangan untuk memusnahkan kehidupan manusia yang tidak bersalah dan ketakutan akan implikasi sosial yang liberal bagi orang lain yang tidak dapat membela diri seperti cacat dan para lanjut usia; (b) Pendirian liberal yang memperbolehkan aborsi dalam berbagai keadaan yang berbeda. Di sini aborsi dipandang sebagai keputusan moral, tetapi dapat menerima pelbagai kemungkinan untuk membenarkannya secara moral, antara lain kualitas hidup janin, kesehatan fisik dan mental wanita, hak wanita atas integritas diri, kesejahteraan keluarga, pertimbangan karier dan keluarga berencana; (c) Pendirian moderat: menempatkan diri di posisi tengah yang mengakui kemungkinan legitimasi moral bagi sementara aborsi, tetapi tidak pernah tanpa mengakui adanya penderitaan dan rasa berat hati baik dari pihak ibu maupun janin. Pendirian ini melihat janin dan wanita sebagai pemilik hak dan mengakui bahwa dalam upaya memecahkan konflik hak seperti itu mau tidak mau akan menyebabkan penderitaan dan rasa berat hati. Dengan demikian pendirian moderat memang menerima kemungkinan terjadinya sesuatu aborsi tertentu, tetapi dapat menerimanya namun dalam suasana tragedi dan sangat kehilangan (Pitono Soeparto, 2001: 105).

Konflik moral mengenai aborsi dapat pula dilihat dari perspektif dunia yang secara radikal berbeda mengenai alam dan seksualitas. Pandangan dunia pertama melihat seksualitas sebagai bagian dari alam. Menurutnya, seksualitas secara alami ditentukan sedemikian rupa, sehingga utamanya memiliki fungsi biologis yang secara intrinsik terkait dengan reproduksi. Karena alam ditentukan dan diawasi oleh Sang Pencipta, maka campur tangan dalam tatanan alamiah melalui kontrasepsi buatan atau aborsi merupakan pelanggaran terhadap tatanan tersebut. Dapatlah dipahami bahwa pandangan seperti ini menjurus ke sikap konservatif tentang masalah abortus. Pandangan dunia yang kedua memahami penyelenggaraan alam bukannya tertuang dalam suatu tatanan biologis yang statis, melainkan merupakan tatanan yang penuh dengan kemurahan hati yang dalam sejarah kemanusiaan menganugerahkan kepada manusia untuk kemungkinan memikul tanggung jawab lebih besar atas diri dan lingkungannya. Seksualitas itu lebih dari sekedar biologis saja. Kontrasepsi adalah cara melaksanakan tanggung jawab dan bukannya suatu pelanggaran dari suatu tatanan biologis. Dalam perspektif ini aborsi pun dimungkinkan secara 
moral.

Pandangan-pandangan dunia yang berbeda ini tidak berhasil menyelaraskan semua perbedaan pendapat antar manusia, tetapi bisa membantu pemahaman terhadap adanya perbedaan pendapat mengenai aborsi. Pihak-pihak yang berselisih memulai dari titik tolak yang berbeda dan mereka mungkin tidak menyadarinya sampai saat terbentur pada suatu perspektif yang mendasar. Dengan demikian perbedaan paham yang paling mendalam bukannya mengenai cara memecahkan suatu masalah moral tertentu seperti aborsi, melainkan mengenai pendapat sejauh mana tanggung jawab kita dan apakah tatanan boleh diubah atau tidak. (Pitono Soeparto, 2001: 106 )

Ada berbagai alasan yang menyebabkan seseorang melakukan aborsi, seperti: kontrasepsi yang gagal, indikasi ekonomi, hamil di luar nikah, kehamilan yang membahayakan kesehatan si ibu dan atau janin yang dikandungnya maupun hamil akibat pemerkosaan. Alasan terakhir inilah yang menjadi pokok permasalahan selanjutnya.

Dalam perspektif etika profesi kedokteran, aborsi pada korban pemerkosaan menimbulkan satu dilema. Sesuai dengan sumpahnya, seorang dokter berkewajiban untuk melindungi hidup insani sejak pembuahan. Dengan demikian aborsi merupakan tindakan yang dilarang. Selain itu dokter juga harus mengutamakan kesehatan penderita. Hal yang dilematis akan terjadi jika dokter menghadapi seorang wanita hamil akibat pemerkosaan yang mengalami trauma psikologis dan berkeinginan untuk mengakhiri hidupnya. Mana yang harus dipilih: (a) melakukan aborsi yang berarti gugurnya janin, atau (b) tidak melakukan aborsi yang berarti nyawa ibu hamil yang menjadi taruhannya?

Sementara itu, dalam hukum positif Indonesia, terdapat 2 (dua) perundang-undangan yang mengatur masalah aborsi, yaitu Kitab UndangUndang Hukum Pidana (KUHP) dan UndangUndang Nomor 36 Tahun 2009 tentang Kesehatan (selanjutnya disingkat UU No. $36 \mathrm{Thn} .2009$ ). KUHP melarang aborsi dengan alasan apapun, sedangkan UU No. 36 Tahun 2009 memperbolehkan aborsi pada korban pemerkosaan. Selain itu, UndangUndang Kesehatan ini juga memperbolehkan aborsi dengan alasan adanya indikasi kedaruratan medis yang dideteksi sejak usia dini kehamilan, baik yang mengancam nyawa ibu dan/atau janin, yang menderita penyakit genetic berat dan/atau cacat bawaan, maupun yang tidak dapat diperbaiki sehingga menyulitkan bayi tersebut hidup diluar kandungan.

Dari latar belakang yang telah diuraikan di atas maka permasalahan yang dapat diidentifikasi adalah sebagai berikut: "Bagaimana aborsi dalam perspektif etika profesi kedokteran, hukum Islam dan peraturan perundang-undangan?" Sebelum permasalahan tersebut dibahas, penulis akan menguraikan terlebih dahulu pengertian dari beberapa istilah yang menjadi kata kunci dalam tulisan ini.

Aborsi berasal dari bahasa Latin abortus yang berarti keguguran atau pengguguran kandungan. Pada dasarnya kata aborsi ini merupakan terjemahan kata abortion dalam bahasa Inggris. Istilah aborsi secara medis diartikan sebagai keluarnya hasil konsepsi (pembuahan) sebelum usia kehamilan 20 minggu (lima bulan) dengan berat kurang dari 500 gram. Hasil konsepsi ini tidak memiliki harapan untuk hidup.

Djoko Prakoso membagi aborsi menjadi dua jenis, yaitu aborsi spontan yang terjadi tanpa usaha dari luar dan aborsi buatan yang dilakukan karena kehamilan yang tidak diinginkan. Golongan kehamilan yang tidak diinginkan ini dirinci lebih lanjut: (a) Tidak diinginkan oleh dokter, karena: (i) Kehamilan tersebut akan mem-bahayakan jiwa ibu; (ii) Anak yang dilahirkan kemungkinan akan cacat berat. Aborsi buatan yang dilakukan karena indikasi medis ini disebut abortus provocatus medisinalis; (b) Tidak diinginkan oleh wanita yang bersangkutan, suaminya atau keluarganya, karena: (i) Pemerkosaan; (b) Hubungan kelamin di luar perkawinan; (b) Alasan-alasan lainnya: sosio ekonomis, anak sudah cukup banyak, belum mampu punya anak. Untuk aborsi jenis ini dipandang sebagai perbuatan pidana atau abortus provocatus criminalis.

Sementara itu Musa Perdanakusuma membagi aborsimenjadi duajenis, yaitu: (a) Abortus spontanea yaitu aborsi yang terjadi dengan sendirinya, dan (b) Abortus provocatus yaitu aborsi yang terjadi karena perbuatan manusia. Aborsi ini dapat terjadi karena alasan medis maupun alasan-alasan lain yang tidak dibenarkan oleh hukum. Dalam ilmu kedokteran, jenis aborsi dibedakan berdasar cara terjadinya, yaitu: (a) Abortus spontanea yaitu aborsi yang terjadi secara spontan tanpa ada suatu tindakan; (b) Abortus provocatus, yaitu aborsi buatan yang terjadi karena ada suatu tindakan.

Ditinjau dari aspek hukum, abortus provocatus 
dapat digolongkan menjadi dua jenis, yaitu: (a) Abortus provocatus legal, yaitu aborsi yang dilakukan menurut syarat dan cara-cara yang dibenarkan oleh Undang-Undang. Alasan yang sangat mendasar adalah untuk menyelamatkan jiwa ibu hamil; (b) Abortus provocatus ilegal, yaitu aborsi yang di dalamnya mengandung unsur kejahatan dan tidak memenuhi syarat dan cara-cara yang dibenarkan oleh Undang-Undang.

Berdasarkan jenis-jenis aborsi yang telah diuraikan sebelumnya, maka penyebab aborsi dapat dikelompokkan menjadi tiga, yaitu: (a) Aborsi karena proses alam; (b) Aborsi karena kelalaian manusia; (c) Aborsi sebagai akibat perbuatan manusia.

Aborsi karena proses alam terjadi tanpa diketahui penyebabnya dan murni merupakan kehendak Tuhan. Inilah yang dikenal dengan istilah aborsi spontan. Namun aborsi juga bisa terjadi karena kelalaian manusia. Ibu yang hamil kurang berhatihati menjaga kandungannya atau mengalami kecelakaan. Selain itu aborsi dapat juga disebabkan tindakan yang sengaja dibuat oleh manusia. Hal ini karena alasan kesehatan ibu yang terancam bahaya maut jika kehamilan itu diteruskan atau alasan lain yang tidak diperbolehkan karena bertentangan dengan hukum.

Menurut ilmu kedokteran, hal-hal yang menyebabkan aborsi dapat dibagi sebagai berikut: (a) Kelainan pertumbuhan hasil konsepsi, Kelainan pertumbuhan hasil konsepsi akan menyebabkan kematiannya atau dilahirkannya dengan cacat. Kelainan berat biasanya menyebabkan kematian janin pada hamil muda. Faktor-faktor yang menyebabkan kelainan dalam pertumbuhan adalah sebagai berikut: (i) Kelainan kromosom, Kelainan yang sering ditemukan pada abortus spontan adalah trisomy dan polypoidy. Juga ada kemungkinan kelainan mengenai kromosom kelamin; (ii) Lingkungan kurang sempurna, Jika lingkungan endometrium di sekitar tempat implantasi kurang sempurna sehingga pemberian zat-zat makanan pada hasil konsepsi terganggu, hal ini dapat menyebabkan kelainan dalam pertumbuhan janin dan kematiannya; (iii) Pengaruh dari luar, radiasi, virus, obat-obat dan sebagainya dapat mempengaruhi baik hasil konsepsi maupun lingkungan hidupnya dalam uterus dan mengakibatkan kematian atau kelainan pertumbuhan janin. Pengaruh ini umumnya dinamakan pengaruh teratogen: (b) Kelainan pada placent, Endarteritis dapat terjadi dalam villi choriales dan menyebabkan oksigenasi melalui placenta terganggu, sehingga menyebabkan gangguan pertumbuhan sampai mengakibatkan kematian janin. Keadaan ini bisa terjadi pada kehamilan 20 minggu atau lebih antara lain karena hipertensi menahun; (b) Penyakit ibu, Penyakit mendadak, seperti pneumonia, typhus abdominalis, pyelonephritis, malaria dan lainlain dapat men-yebabkan abortus. Anemia berat, keracunan, laparotomi, peritonitis dan penyakit menahun seperti brucellosis, mononucleosis infectiosa, toxoplasmosis juga dapat menyebabkan abortus walaupun lebih jarang; (d) Kelainan tractus genitalis, Kelainan uterus dapat menyebabkan abortus. Selain itu abortus juga dapat terjadi disebabkan kelemahan bawaan pada cervix, dilatasi cervix berlebihan, pemotongan cervix atau robekan cervix luas yang tidak dijahit (Sarwono Prawirohardjo, 1976: 239).

Sementara itu yang dimaksud dengan pemerkosaan adalah tindak kekerasan atau kejahatan seksual yang dilakukan oleh laki-laki terhadap perempuan dengan kondisi: (a) Tidak atas persetujuan dan kehendak perempuan; (b) Dengan persetujuan perempuan namun di bawah ancaman; (c) dengan persetujuan perempuan namun melalui penipuan.

Selanjutnya akan kita uraikan pengertian dan ruang lingkup etika profesi kedokteran. Secara umum etika berasal dari bahasa Latin ETHOS yang artinya adalah yang baik atau yang layak. Ini merupakan kaidah, nilai atau norma-norma yang dipegang kelompok profesi tertentu dalam memberikan pelayanan jasa kepada masyarakat. Kepustakaan menyebutkan "ETHICS" is a dicipline dealing with what is good and what is bad. It is concerned with standart of conduct. (Hermien H.K, 2006: 62). Dari sini bisa diambil pengertian bahwa etika adalah kesepakatan mengenai apa yang baik dan apa yang buruk sesuai standar keahliannya. Sedangkan profesi itu pada hakikatnya adalah suatu lapangan pekerjaan (okupasi) yang berkualifikasi yang menuntut syarat keahlian tinggi kepada para pengemban dan pelaksananya. Pada dasarnya ada tiga kriteria utama untuk mengkualifikasi apakah suatu okupasi itu boleh dibilang suatu profesi atau tidak (Soetandyo, 2002: 316).

Yang pertama ialah bahwa profesi itu berbeda dengan okupasi biasa akan dilaksanakan atas dasar keahlian yang tinggi, dan karena itu hanya dapat dimasuki oleh mereka yang telah menjalani pendidikan dan pelatihan teknis yang amat lanjut; 
sehubungan dengan hal itu, setiap profesi pun selalu mengembangkan pranata dan lembaga untuk menetapkan standar keahlian yang diperlukan untuk mengefektifkan jasa profesi, dan sekaligus juga menilai kemampuan individu-individu yang menjalani profesi itu (untuk menjaga agar standar keahlian tetap terjaga) .

Kedua ialah bahwa profesi itu mensyaratkan agar keahlian yang dipakainya selalu berkembang secara nalar dan dikembangkan dengan teratur seiring dengan kebutuhan masyarakat yang minta dilayani oleh profesi yang me-nguasai keahlian profesional itu; dengan demikian standar keahlian yang dituntut oleh profesi tidaklah akan statis dan konservatif, melainkan selalu dinamik dan progresif, bersejalan dengan perkembangan masyarakat yang harus dilayani oleh profesi tersebut.Ketiga, profesi itu selalu mengembangkan pranata dan lembaga untuk mengontrol agar keahlian-keahlian profesional didayagunakan secara bertanggung jawab, bertolak dari itikad pengabdian yang tulus dan tak berpamrih, dan semua itu dipikirkan untuk kemaslahatan sesama.

Dari penegasan-penegasan tentang pengertian profesi sebagaimana disebutkan dimuka, tampaklah bahwa apa yang disebut profesi itu sesungguhnya bertumpu kuat-kuat pada suatu paham atau ideologi. Inilah paham atau ideologi profesionalisme, yang sebagaimana selalu dapat kita simak berkomponen dua: komponen tehnik dan ketika. Adapun ciriciri dari pekerjaan profesi adalah sebagai berikut: (a) mengikuti pendidikan sesuai standar nasional; (b) pekerjaannya berlandaskan ketika profesi; (c) mengutamakan panggilan kemanusiaan daripada keuntungan; (d) pekerjaannya legal melalui perizinan; (e) anggota-anggotanya belajar sepanjang hayat; (f) anggota-anggotanya bergabung dalam suatu organisasi profesi (M. Jusuf Hanafiah \& Amri Amir, 1994: 2).

Pekerjaan dokter merupakan salah satu pekerjaan profesi. Dengan demikian dalam menjalankan pekerjaannya, seorang dokter terikat dengan etika profesinya.

\section{ABORSI KORBAN PERKOSAAN DALAM PERSPEKTIF HUKUM ISLAM}

Sebagaimana telah diuraikan sebelumnya, sampai saat ini aborsi tetap menjadi masalah dalam bidang kesehatan dan selalu menimbulkan pro dan kontra. Para ahli agama memandang aborsi sebagai perbuatan dosa dan apapun alasannya aborsi tidak boleh dilakukan. Ahli medis juga menentang aborsi tetapi jika hal itu untuk menyelamatkan nyawa sang ibu maka mereka dapat memahami dilakukannya aborsi tersebut. Ahli ekonomi berpendapat bahwa alasan ekonomi tidak dapat dijadikan sebagai indikasi aborsi buatan.

Mengenai pandangan para ahli agama terkait aborsi bagi korban pemerkosaan, maka dalam tulisan ini penulis akan mengulasnya dari perspektif agama Islam yang penulis rangkum dari buku Fikih Kedokteran karya M. Nu'aim Yasin terdapat pro dan kontra terhadap aborsi bagi korban pemerkosaan yang disampaikan para ahli fikih kedokteran Islam. Yang menjadi titik acuannya adalah hukum aborsi sebelum peniupan roh. Jika aborsi tersebut dilakukan setelah peniupan roh, maka jelas hukumnya adalah haram.

Banyak perbedaan pendapat diantara beberapa madzhab fikih, seperti madzhab Hanafi, madzhab Maliki, madzhab Syafi'i dan juga madzhab Hambali. Di bawah ini akan diuraikan mengenai pendapat masing-masing madzhab tersebut.

Madzhab Hanafi memperbolehkan aborsi sebelum peniupan roh jika kedua orangtuanya sebagai pemilik janin itu mengizinkan. Argumen yang diberikan adalah sebelum peniupan roh belum terjadi penciptaan apa pun pada janin. Mereka menetapkan waktu setelah seratus dua puluh hari (empat bulan) sebagai waktu terbentuknya janin. Pendapat ini memunculkan permasalahan karena dalam kitab Al Bahr dijelaskan bahwa janin sudah terbentuk pada usia dua kali empatpuluh hari $(80$ hari).

Sementara itu para ulama madzhab Maliki memberikan pandangan yang berbeda tentang hukum aborsi sebelum peniupan roh. Ada yang mengharamkan aborsi setelah air mani berada dalam rahim, ada yang memakruhkan aborsi sebelum janin berusia empatpuluh hari dan mengharamkannya sesudah itu. Madzhab Syafi'i mengharamkan aborsi setelah peniupan roh dan dibolehkan jika dilakukan sebelumnya.

Madzhab Hambali secara umum berpendapat membolehkan aborsi dengan usia janin maksimal empatpuluh hari, setelah usia janin empat puluh hari tidak boleh dilakukan aborsi. Ulama ulama lain, yaitu Ibnul Jauzi yang mengharamkan aborsi sebelum peniupan roh di semua fase perkembangan janin. Sebagian ulama madzhab Hambali ada juga yang membolehkan aborsi sebelum peniupan roh secara mutlak tanpa mensyaratkan fase-fase tertentu 
dari perkembangan janin. Para ulama sepakat menyatakan bahwa pembunuhan janin setelah berumur 4 (empat) bulan adalah haram berdasarkan secara umum ayat-ayat tentang larangan pembunuhan dan secara khusus berdasarkan firman Allah SWT: "Dan janganlah kamu membunuh anak-anakmu karena takut kemiskinan. Kamilah yang akan memberi rezeki kepada mereka dan juga kepadamu. Sesungguhnya membunuh mereka adalah suatu dosa yang besar" (Q.S. Al-Isra' 17: 31).

Aborsi yang dibolehkan berdasarkan ijtihad para ulama hanyalah aborsi yang dilakukan oleh dokter atau tenaga kesehatan lainnya berdasarkan indikasi medis untuk menyelamatkan jiwa ibu yang terancam bila kelangsungan kehamilan dipertahankan. Dalam kasus ini para ulama memilih yang paling sedikit resikonya dari dua hal yang mendatangkan mudharat (irtikab akhaffi adhdharain), sedangkan aborsi yang dilakukan bukan atas dasar indikasi medis seperti karena kondisi ekonomi, itu yang disebut dengan aborsi kriminalis dan haram hukumnya menurut ijtihad para ulama karena menghentikan proses kehidupan seorang insan.

\section{FATWA MAJELIS ULAMA INDONESIA TENTANG ABORSI}

Majelis Ulama Indonesia sudah mengeluarkan Fatwa tentang aborsi pada tanggal 12 Rabi'ul Akhir $1426 \mathrm{H}$, bertepatan dengan tanggal $21 \mathrm{Mei}$ 2005, sebagai berikut: (a) Bahwa akhir-akhir ini banyak terjadi tindakan aborsi yang dilakukan oleh masyarakat tanpa memperhatikan tuntunan agama; (b) Bahwa aborsi tersebut banyak dilakukan oleh pihak-pihak yang tidak memiliki kompetensi sehingga menimbulkan bahaya bagi ibu yang mengandungnya dan bagi masyarakat pada umumnya; (c) Bahwa aborsi sebagaimana yang terdapat pada point a dan (b) telah menimbulkan pertanyaan masyarakat tentang hukum melakukan aborsi, apakah haram secara mutlak ataukah boleh dalam kondisi-kondisi tertentu; (d) Bahwa oleh karena itu, MUI memandang perlu menetapkan fatwa tentang hukum aborsi untuk dijadikan pedoman.

Kemudian mengingat firman Allah dalam surat Al-An'am 1521, Al Isra' 31, Al Furqan 63-71, Al-Hajj 5, Al-Mukminun 12-14, dan hadist Nabi riwayat Bukhori dari Abdullah RA, hadist Nabi riwayat Ibnu Majah dari. Dari berbagai pendapat yang sudah dipaparkan di atas, terlihat bahwa masalah aborsi bagi korban pemerkosaan memang menimbulkan pro dan kontra yang tidak mudah mencari solusinya.

\section{ABORSI KORBAN PERKOSAAN DALAM PERSPEKTIF ETIKA KEDOKTERAN}

Saat seorang mahasiswa kedokteran menyelesaikan pendidikannya, dilaksanakan upacara pelantikan yang disertai dengan pengucapan lafal sumpah dokter. Adapun bunyi lafal sumpah dokter tersebut adalah sebagai berikut: "Demi Allah saya bersumpah/berjanji, bahwa: (a) Saya akan membaktikan hidup saya guna kepentingan perikemanusiaan; (b) Saya akan memelihara dengan sekuat tenaga martabat dan tradisi luhur jabatan kedokteran; (c) Saya akan menjalankan tugas saya dengan cara yang terhormat dan bersusila, sesuai dengan martabat pekerjaan saya sebagai dokter; (d) Saya akan menjalankan tugas saya dengan mengutamakan kepentingan masyarakat.

Pro dan kontra terkait aborsi bagi korban pemerkosaan tidak saja terjadi di kalangan para ahli. Perbedaan itu juga terlihat pada perundangundangan yang menjadi hukum positip negara kita. KUHP melarang abortus dengan alasan apapun dan siapapun juga yang melakukannya akan dikenai sanksi pidana. Hal itu diatur dalam pasal 299, 346349 KUHP.

Dengan demikian aborsi terhadap korban pemerkosaan dapat dilegalkan tetapi tetap diberlakukan dengan teliti, tepat dan cermat, dalam artian bahwa pelaku benar-benar mereka adalah korban pemerkosaan, dan dokter yang melakukan aborsi adalah tenaga kesehatan yang profesional dengan mengikuti standar profesi dan pelayanan yang berlaku, serta tidak diskriminatif dengan memperhatikan ketentuan yang diatur dalam peraturan perundang-undangan serta norma-norma agama yang berlaku. Dari bunyi pasal-pasal tersebut di atas terlihat bahwa KUHP melarang abortus tanpa terkecuali sehingga abortus provocatus medisinalis juga tidak diperbolehkan. Tentunya hal ini memberatkan apabila kalangan medis terpaksa melakukan abortus demi menyelamatkan jiwa ibu yang mengandung. Perkembangan selanjutnya terlihat pada pasal 75-77 UU No. 36 tahun 2009. Dalam pasal itu abortus provocatus medisinalis diperbolehkan.

Berdasarkan uraian tersebut di atas, terlihat bahwa terdapat perbedaan antara KUHP dengan 
UU No. 36 tahun 2009 dalam mengatur abortus provocatus medisinalis. Pro dan kontra ini akan menimbulkan permasalahan jika terjadi kasus abortus dengan alasan indikasi medis. Peraturan mana yang akan diterapkan?

Untuk menganalisa permasalahan yang terjadi akibat pro dan kontra terhadap abortus provocatus medisinalis, penulis akan mengupasnya dengan melihat beberapa asas dalam hukum kita. Jika terjadi pertentangan antara peraturan yang lama (KUHP) dengan peraturan yang baru (UU No. 36 tahun 2009) padahal peraturan tersebut mengenai hal yang sama, maka berlaku asas lex posteriori derogat legi priori, yaitu jika ada peraturan baru yang me-ngatur materi yang sama sementara peraturan lama tidak dicabut dan bertentangan satu sama lain maka peraturan yang baru itu mengalahkan peraturan yang lama. Selain itu juga berlaku asas lex specialis derogat lex generalis, yaitu peraturan yang bersifat khusus mengalahkan peraturan yang bersifat umum. Dalam hal ini UU No. 23 Tahun 1992 adalah lex specialis, sementara KUHP adalah lex generalis.

Abortus provocatus medisinalis diperbolehkan di Indonesia sesuai dengan ketentuan Pasal 75-77 UU No. 36 tahun 2009. Berdasarkan bunyi pasal tersebut, maka syarat-syarat dilakukannya tindakan itu adalah:

Dalam Deklarasi Oslo (1970) disebutkan bahwa moral dasar yang harus dijiwai oleh seorang dokter adalah butir lafal sumpah: "Saya akan menghormati hidup insani sejak saat pembuahan". Karena itu abortus provocatus medisinalis hanya dilakukan jika memenuhi syarat-syarat sebagai berikut : (a) Aborsi. hanya dilakukan berdasar indikasi medis; (b) Suatu keputusan untuk menghentikan kehamilan, sedapat mungkin disetujui secara tertulis oleh dua orang dokter yang dipilih berkat kompetensi profesional mereka; (c) Prosedur itu hendaklah dilakukan oleh seorang dokter yang kompeten di instalasi yang diakui oleh suatu otoritas yang sah; (d) Jika dokter itu merasa bahwa hati nuraninya tidak membenarkan ia melakukan abortus tersebut, maka ia berhak mengundurkan diri dan menyerahkan pelaksanaan tindakan medis itu kepada sejawatnya yang lain yang kompeten. Menurut UU No. 36 tahun 2009 indikasi medis akan diberikan oleh tenaga kesehatan yang kompeten. Tetapi pembentuk UU sudah menentukan bahwa indikasi medis tersebut adalah jika nyawa sang ibu dan atau janinnya terancam bahaya maut. Sebagaimana yang sudah diuraikan sebelumnya, dalam prakteknya indikasi medis itu juga mengenai anak yang akan dilahirkan nanti.

Ada beberapa kondisi kehamilan merupakan indikasi medis bagi anak yang akan dilahirkan nanti. Misal pada saat hamil sang ibu menderita penyakit campak Jerman. Penyakit ini memang tidak berbahaya bagi sang ibu, tetapi membahayakan sang anak yang akan lahir nanti karena ibu hamil yang melahirkan penderita penyakit ini maka anak yang dilakan mengalami cacat berat. Masih banyak penyakit-penyakit lain yang jika diderita oleh ibu hamil akan mengancam kesehatan sang anak.

\section{PENUTUP}

Dari Pembahasan yang telah diuraikan sebelumnya, maka mengakhiri tulisan ini dapat diambil kesimpulan sebagaimana di bawah ini:

Aborsi bagi korban pemerkosaan dalam perspektif etika kedokteran menimbulkan suatu dilema. Kalau dilakukan berarti dokter telah melanggar sumpahnya yaitu berkewajiban melindungi hidup makhuk insani sejak saat pembuahan, selain itu dalam sumpahnya dokter juga harus mengutamakan kesehatan penderita. Dengan demikian jika aborsi tidak dilakukan maka akan mengancam nyawa ibu hamil yang mengalami ikut psikologis dan berkeinginan untuk mengakhiri hidupnya.

Ditinjau dari hukum Islam aborsi juga menimbulkan banyak perbedaan pendapat baik menurut mahzab Hanafi, Maliki, mahzab Syaii, dan juga mahzab Hambali. Pada prinsipnya aborsi diharamkan tetapi berdasar itjtihad para ulama aborsi dibolehkan jika dilakukan oleh dokter atau tenaga kesehatan yang berwenang berdasar indikasi medis menyelamatkan jiwa ibu.

Sementara itu dalam perundang-undangan Indonesia terdapat perbedaan antara KUHP dengan Undang-Undang No. 36 Tahun 2009 dalam mengatur masalah aborsi, KUHP melarang aborsi dalam apapun sedangkan Undang-Undang Kesehatan membolehkan aborsi pada korban pemerkosaan yang hamil.

\section{DAFTAR PUSTAKA}

\section{Buku:}

Abdulkadir, Muhammad, 2004, Hukum dan Penelitian Hukum, Bandung: Citra Aditya Bakti.

Abdul Wahid dan Muhammad Irfan, 2001, Perlindungan terhadap Korban Kekerasan 
Seksual, Bandung: Refika Aditama.

Bambang Sunggono, 2005, Metodologi Penelitian Hukum, Jakarta: Raja Grafindo Persada.

Bahder Johan Nasution, 2005, Hukum Kesehatan, Jakarta: Rineka Cipta.

Etty Indriati, 2005, Menulis Karya Ilmiah, Jakarta: Gramedia.

M. Jusuf Hanafiah dan Amri Amir, 1994, Etika Kedokteran dan Hukum Kesehatan, Jakarta: EGC.

Pitono Soeparto, dkk (ed.), 2001, Etik dan Hukum di Bidang Kesehatan, Komite Etik Rumah Sakit, Surabaya: RSUD Dr. Soetomo.

Wila Chandrawila Supriadi, 2001, Hukum Kedokteran, Bandung: Mandar Maju.

\section{Hand out kuliah:}

Indrati Rini, (2006). Metodologi Penelitian Hukum, Program Magister Ilmu Hukum Universitas Wijaya Kusuma Surabaya.

\section{Undang-Undang:}

Undang-Undang Nomor 36 Tahun 2009 tentang Kesehatan.

Kitab Undang-Undang Hukum Pidana.

\section{Jurnal/Seminar:}

Yunahar Ilyas, 2009, Aborsi terhadap Perempuan Korban Perkosaan dalam Pandangan Hukum Islam, Seminar Nasional, Fakutas Hukum dan Fakultas Kedokteran, Universitas Wijaya Kusuma Surabaya. 